\title{
THE REGENT SURGE OF WALSH GLACIER, YUKON AND ALASKA
}

\author{
By Austin Post \\ (U.S. Geological Survey, Tacoma, Washington, U.S.A.)
}

\begin{abstract}
Aвstract. Walsh Glacier, Yukon and Alaska, after 40 years or more of virtual stagnation in the terminal area, began a very rapid surge in late 1960 or $196 \mathrm{I}$. A maximum movement of $10 \cdot 1 \mathrm{~km}$. occurred in the central portion of the glacier between 1961 and 1965 , as shown by aerial photographs of the displacement of surface features, perhaps the greatest such displacement yet reported for any surging glacier.
\end{abstract}

RÉsumé. La récente avance du Walsh Glacier, Yukon et Alaska. Le Walsh Glacier, Yukon et Alaska, après 40 années ou plus de stagnation virtuelle de la zone terminale, commença une avance très rapide fin ig6o ou 1961. La partie centrale du glacier présenta un mouvement maximum de $10, \mathrm{r} \mathrm{km}$ entre 1961 et 1965, montré par le déplacement d'accidents superficiels sur des photographies aériennes, peut-être la plus grande avance rapportée d'un glacier en crue.

Zusammenfassung. Der rezente Vorstoss des Walsh-Gletschers, Yukon und Alaska. Der Walsh-Gletscher in Yukon und Alaska begann nach 40 oder mehr Jahren praktischer Stagnation des Zungengebietes im Spätjahr I96o oder 196 I einen sehr schnellen Vorstoss. Wie aus Verlagerungen von Oberflächenerscheinungen in Luftaufnahmen hervorgeht, trat zwischen ${ }_{196}{ }_{1}$ und ${ }_{1965}$ ein Bewegungsmaximum von $10,1 \mathrm{~km}$ im Mittelteil des Gletschers ein, vielleicht die grösste derartige Verlagerung, die je an einem vorstossenden Gletscher festgestellt wurde.

\section{General Description}

Walsh Glacier, which crosses the Yukon-Alaska border at lat. $60^{\circ} 55^{\prime} \mathrm{N}$. is $75 \mathrm{~km}$. in length. It heads in the Icefield Ranges, Yukon Territory, Canada, in two major branches, one from the north and one from the east, each $27 \mathrm{~m}$. long. Below their juncture the glacier trends in a westerly direction into Alaska and joins the Logan Glacier $16 \mathrm{~km}$. above the latter's terminus. The two glaciers merge at an elevation of $1,130 \mathrm{~m}$. Logan Glacier terminates very close to Chitina Glacier and is generally mapped as joining the latter (Fig. I).

The accumulation area of Walsh Glacier covers about $545 \mathrm{~km} .{ }^{2}$. The firn line is located at $2,320 \mathrm{~m}$. The ablation area covers $285 \mathrm{~km} .{ }^{2}$. The accumulation area ratio (Meier and Post, I 962, p. 7o) is $0 \cdot 66$. The insulating effect of heavy ablation moraine reduces the melting on $67 \mathrm{~km}^{2}$ of glacier surface. The high accumulation area ratio and the limited amount of exposed ice in the ablation area suggest that this is a very healthy glacier.

\section{PAST Records}

Very little has been written regarding Walsh Glacier. The International Boundary Commission mapped most of the glacier in about 1912. Their detailed map shows that the party crossed the Walsh where it joins the Logan and occupied two photo points overlooking the valley. Bradford Washburn photographed the lower portion of the glacier in 1938 and the U.S. Air Force took trimetrogon photos in 1948. Canadian government mapping photographs were obtained in $195^{\mathrm{I}}$ and U.S. Geological Survey aerial photographs covering the Alaskan part of the glacier were taken in 1957. The writer has examined and photographed portions of the glacier in $1960,1961,1963$, 1964, and 1965 in the course of aerial photographic studies of north-west North American glaciers.

\section{Past Behavior}

All photographs and maps prior to 1963 show that the lower portion of the Walsh Glacier was heavily covered with an ablation moraine and apparently stagnant.* It is quite likely that

* The term stagnant as used here describes glacier ice displaying no detectable movement on careful visual inspection of comparative aerial photographs spanning a period of five years or more. A movement of $20 \mathrm{~m}$. is considered to be detectable in the photographs of Walsh Glacier. 


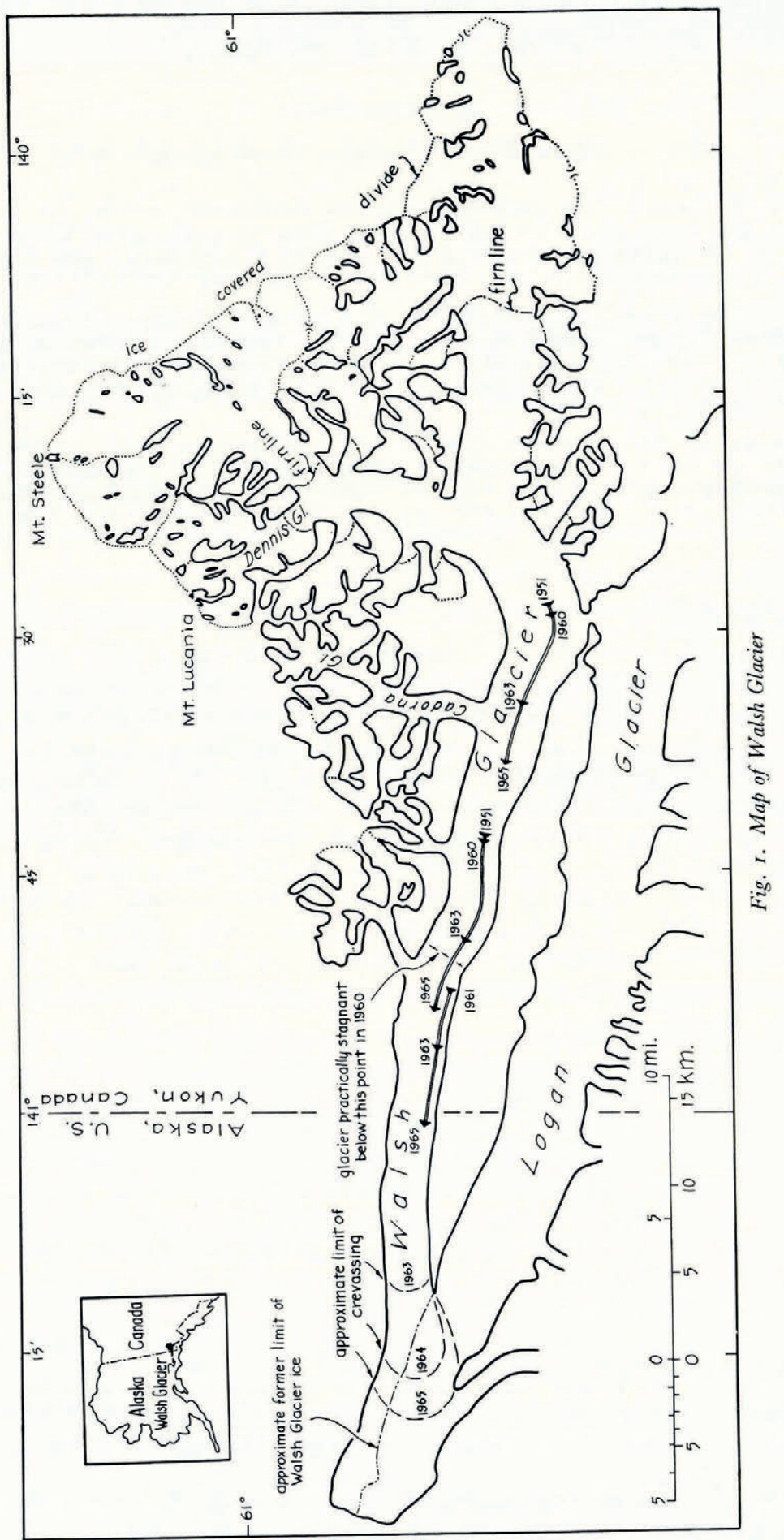


the glacier made an unrecorded surge (as defined below) sometime between the boundary commission surveys and about I 9 I 8 . The $193^{8}$ photographs show surface features that indicate the lower Walsh Glacier had then been stagnant for probably $20 \mathrm{yr}$. or more. Except for further loss of ice through melting, the 1948 and ig6r photography showed that little further change had taken place. Between $195^{1}$ and 1961 no evidence of movement was found in the Walsh Glacier below the first tributary.

\section{Regent Surge}

Evidence of rapid down-valley movement of ice was apparently first noted in 1963 (Post, I964, p. I4). Various changes which took place in the lower part of the glacier between 1952 and 1964 have been described by Paige ( 1965 ).

From the photographic records the recent movement of portions of the glacier have been determined. This movement of the ice and other related features are typical of a glacier surge* (Post, i96o; r965).

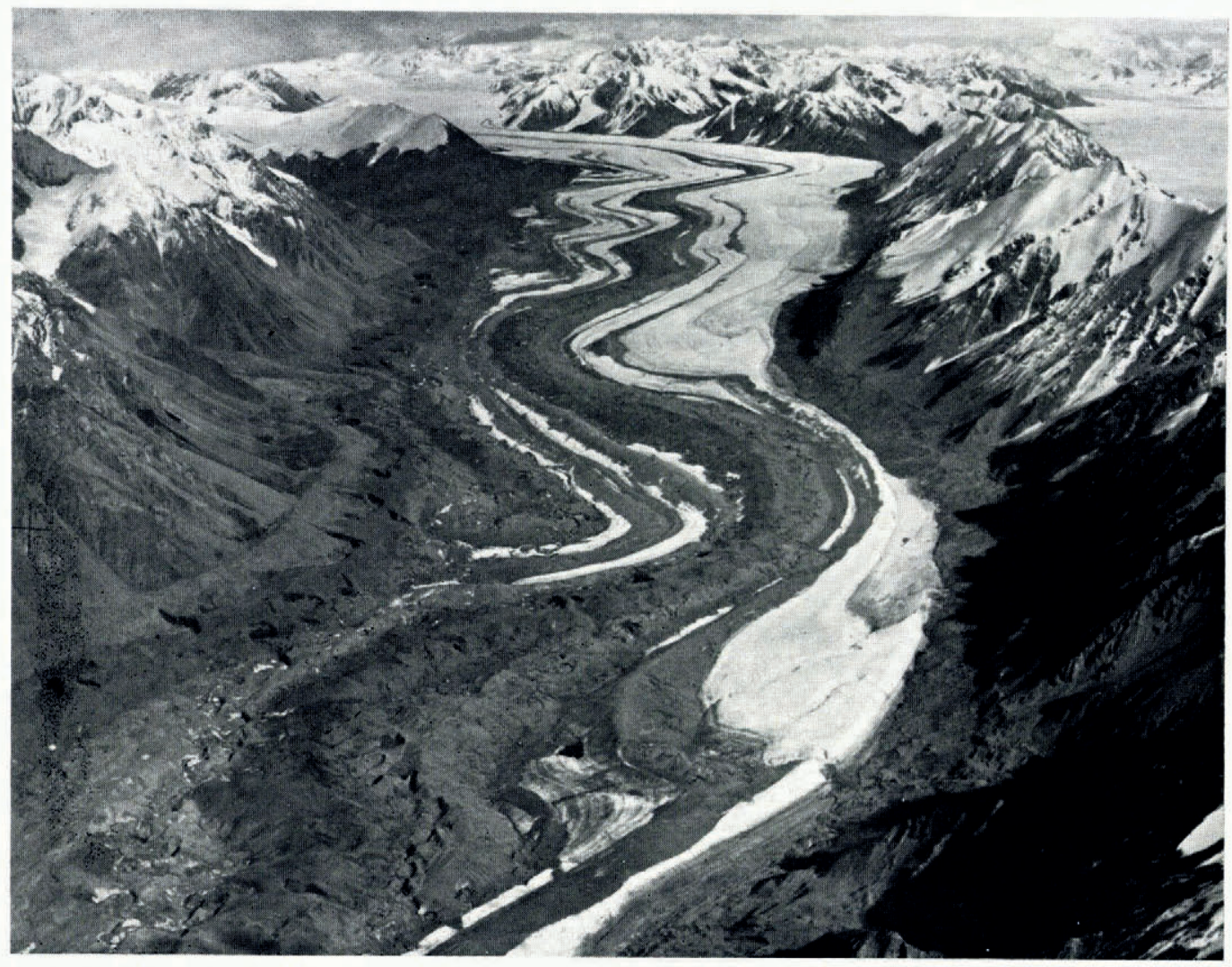

Fig. 2. Central section of Walsh Glacier 21 August 1960. The medial moraine loops are little changed from positions shown in photographs taken in $193^{8}$ and 195 I. Note the smooth, uncrevassed ice between medial moraines. The glacier down-valley from the area shown here was covered with irregular ablation moraine and appeared to be essentially stagnant in all photographs prior to 1963 . (Photograph by Austin Post, University of Washington)

* The term "advance" has been frequently used to describe rapid movements similar to the Walsh Glacier surge. The term is generally technically incorrect as the affected glaciers rarely advance beyond their former limits. The term "surge" is suggested to describe large-scale, short-lived glacier movements whether a terminal advance occurs or not. 
The Walsh Glacier surge has been exceptional in the distance the ice has moved down the valley. In a period of $4 \mathrm{yr}$. or less the maximum movement yet determined amounts to $\mathrm{IO} \cdot \mathrm{I} \pm 0 . \mathrm{I} \mathrm{km}$. To the author's knowledge, this is greater than any such displacement previously reported for surging glaciers* (Tarr and Martin, I9I4; Desio, I954; Dolgushin and others, I963; Hance, I937; Moffit, I942; Post, I96o; Hattersley-Smith, r 964). The maximum average annual movements in the central part of the glacier during the $195^{\mathrm{I}-60}, \mathrm{I} 95^{\mathrm{I}-6} \mathrm{I}$, 1960-63, and $1963-65$ intervals are listed in Table I. Movement vectors for these time

Table I. Recent Movement of Walsh Glacier

\begin{tabular}{|c|c|c|c|c|c|}
\hline Part of glacier & $\begin{array}{l}195 \mathrm{I}-60 \\
\mathrm{~m} .\end{array}$ & $\begin{array}{l}195 I-6 I \\
\mathrm{~m} .\end{array}$ & $\begin{array}{c}1960-63 \\
\mathrm{~m} .\end{array}$ & $\begin{array}{c}{ }_{196 I-63}^{6}-63 \\
\mathrm{~m} .\end{array}$ & $\begin{array}{c}{ }_{1963-65}-65 \\
\mathrm{~m} .\end{array}$ \\
\hline $\operatorname{ary}$ & - & $0 \pm 20$ & - & $3,35^{\circ} \pm 5^{\circ}$ & $4,260 \pm 5^{\circ}$ \\
\hline & $300 \pm 20$ & - & $5,640 \pm 5^{\circ}$ & - & $4,4^{10} \pm 5^{\circ}$ \\
\hline & $760 \pm 100$ & - & $5,330 \pm 100$ & - & $3,35^{\circ} \pm 5^{\circ}$ \\
\hline
\end{tabular}

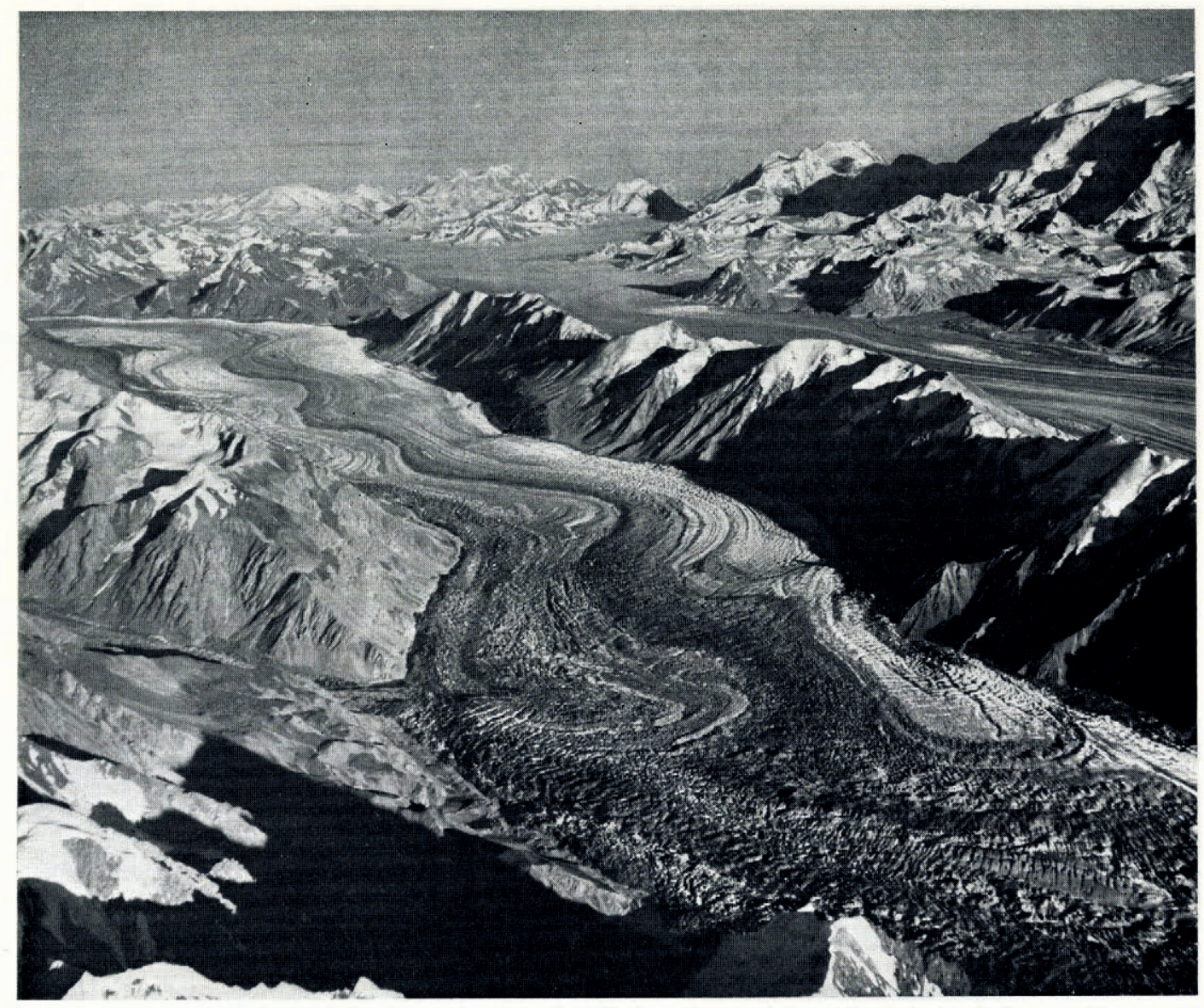

Fig. 3. Central section of Walsh Glacier 24 August 1963 . The formerly smooth ice surface is broken by innumerable crevasses. A maximum down-valley movement of $5,640 \mathrm{~m}$. has taken place since 1960 , as shown by the displacement of medial moraine loops. "First Tributary" enters at lower left, Logan Glacier and Mt. Logan $(5,405 \mathrm{~m}$.) are on right. (Photograph by Austin Post, University of Washington)

* The Kutiah Glacier advance may have been greater, but its initial condition does not appear to be accurately known. [Note added in proof:] Since the manuscript of this paper was submitted, a glacier advance of $21 \mathrm{~km}$. in $3 \mathrm{yr}$. has come to the author's attention (Glen, 194I). 
intervals are shown on Figure I. As these figures represent averages over periods which may be considerably greater than the interval that the glacier has been in rapid motion, the actual maximum rate of flow is doubtless greater. The 1961 photography shows the central portion of the glacier from too great a distance to make accurate measurements possible. Despite this there can be little doubt that surface features in that region were essentially unchanged from I960 (Fig. 2).

That this "advance" (surge) may have been caused by the 27 March i 964 earthquake has been suggested by Paige (1965, p. 877). The extensive movement which took place before August 1963 (Fig. 3) precludes this possibility. From the amount of movement recorded between 1960 and 1963 the writer believes that the surge began in the upper portion of the glacier either in late 1960 or in 1961 ; 1965 photography suggests that the surge has probably about completed its active cycle.

In the upper source areas of the glacier the ice thickness had been reduced from its I96o levels as much as $150 \mathrm{~m}$. (Figs. 4 and 5 ), which is about the maximum amount observed in other surging glaciers. The relative absence of fresh fractures in the ice in this area in ${ }_{9} 965$ suggests that the rate of flow was much reduced.

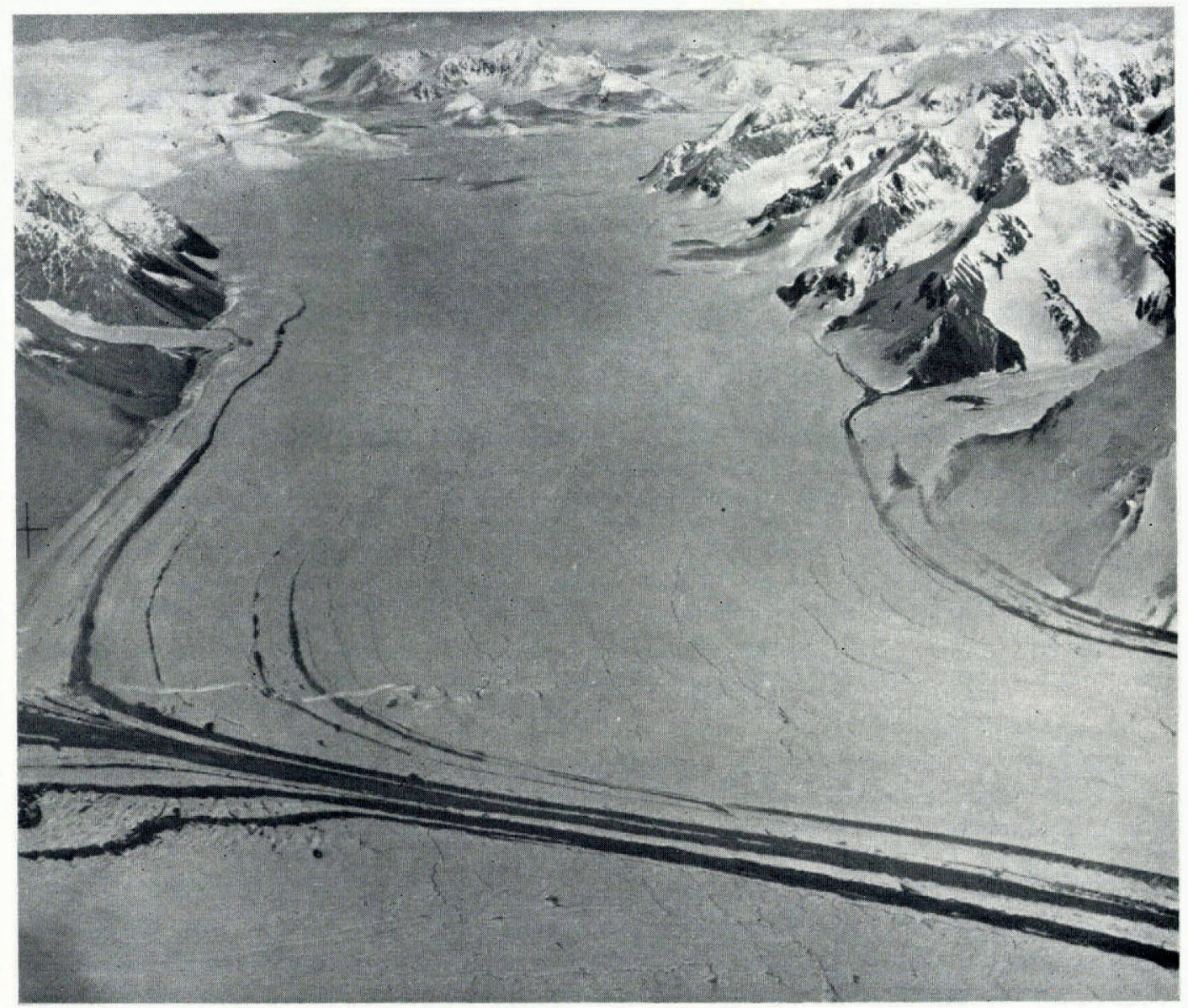

Fig. 4. East Branch, Walsh Glacier, 21 August 1960. The smooth ice and surface melt-water channels attest to the absence of crevasses. The deeply cut (white) melt-water channel crossing the medial moraines in the lower left side of the photo was present when the glacier was photographed in 19.5I. (Photograph by Austin Post, University of Washington) 


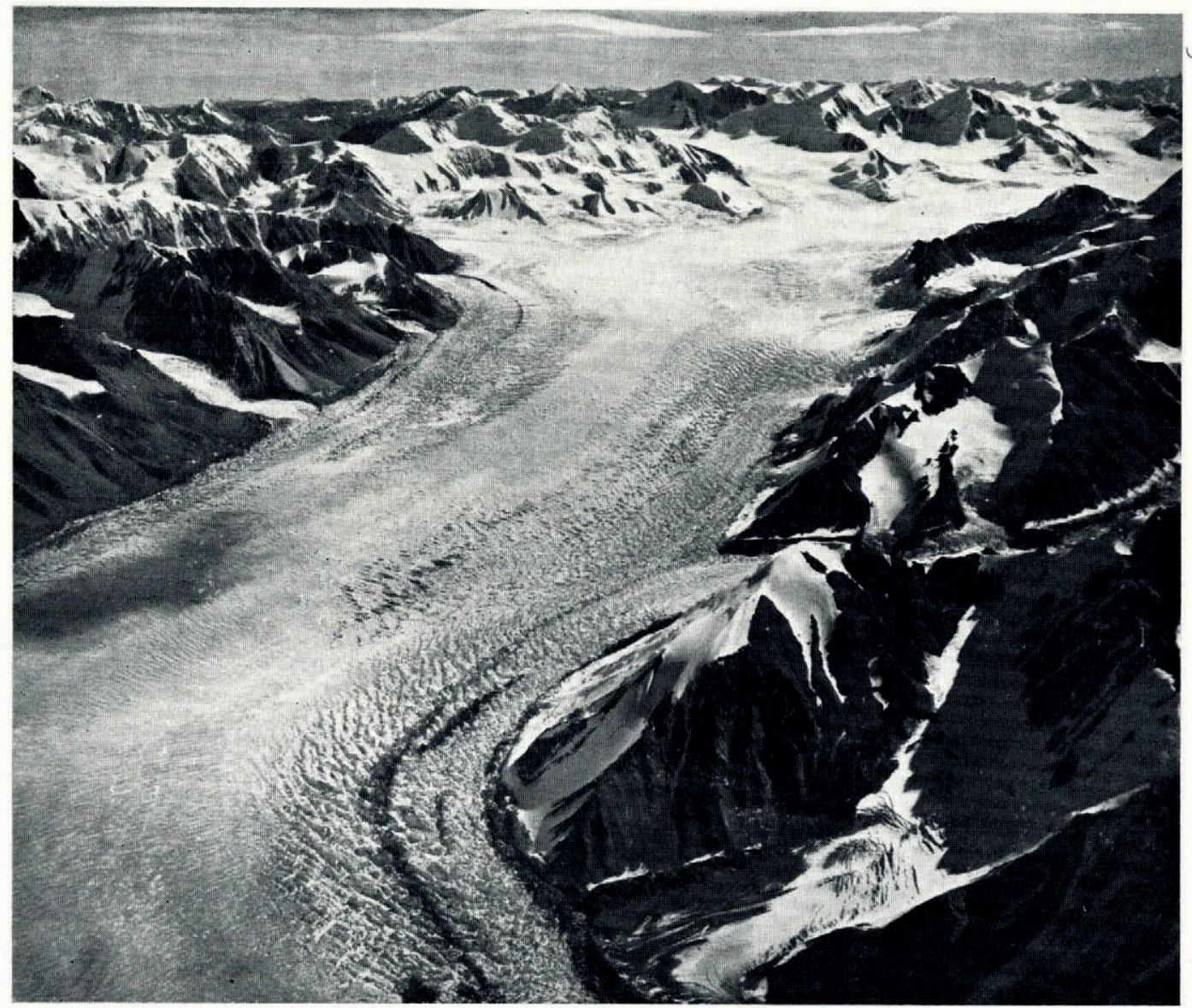

Fig. 5. East Branch, Walsh Glacier, 23 August 1965 . The glacier has been completely transformed. The margins of the glacier are intensely crevassed and the surface has been lowered $60 \mathrm{~m}$. or more. Farther up the glacier lowering of the surface appears to be as much as I50 $\mathrm{m}$. Note the ice affixed to valley walls which shows the level of the glacier before the surge took place. Ice flowing into Walsh Glacier from various tributaries is here clearly evident. (Photograph by Austin Post, U.S. Geological Survey)

Other glaciers in this region have made surges in recent years and at least one appears to be in the initial stages of a surge in ${ }_{1965}$. These glaciers are being kept under careful observation and, when possible, photographed annually.

\section{Acknowledgement}

This study was made possible by aerial photographic studies sponsored from i 960 to 1963 by the National Science Foundation and administered by the University of Washington. The U.S. Geological Survey sponsored the 1964 and 1965 studies.

\section{MS. received I February 1966}

\section{REFERENCES}

Desio, A. 1954. An exceptional glacier advance in the Karakoram-Ladakh region. Fournal of Glaciology, Vol. 2, No. 16 , p. $383^{-85}$.

Dolgushin, L. D., and others. 1963 . Nedavneye nastupleniye Lednika Medvezh'yego [The recent advance of the Medvezhiy glacier], [by] L. D. Dolgushin, S. A. Yevteyev, A. N. Krenke, K. G. Rototayev [and] N. M. Svatkov. Priroda [Nature], i963, No. II, p. 85-92. [English translation: Canada. Defence Research Board. Report No. T 409 R, translated by E. R. Hope, 1964.] 
Glen, A. R. 1941. The latest map of North East Land. Geographical Journal, Vol. 98, No. 4, p. $206-07$.

Hance, J. H. 1937. The recent advance of Black Rapids Glacier, Alaska. Journal of Geology, Vol. 45, No. 7, p. $775-83$.

Hattersley-Smith, G. 1964. Rapid advance of glacier in northern Ellesmere Island. Nature, Vol. 201, No. 4915, p. 176 .

Meier, M. F., and Post, A. S. 1962. Recent variations in mass net budgets of glaciers in western North America. Union Géodésique et Géophysique Internationale. Association Internationale d’Hydrologie Scientifique. Commission des Neiges et Glaces. Colloque d'Obergurgl, 10-9-18-9 1962, p. 63-77.

Moffit, F. H. 1942. Geology of the Gerstle River district, Alaska. U.S. Geological Survey. Bulletin 926-B, p. $146-57$.

Paige, R. A. I965. Advance of Walsh Glacier. Journal of Glaciology, Vol. 5, No. 42, p. 876-78. [Letter.]

Post, A. S. 1960. The exceptional advances of the Muldrow, Black Rapids, and Susitna Glaciers. Fournal of Geophysical Research, Vol. 65, No. 11, p. 3703-12.

Post, A. S. 1964. Aerial photography in 1963 . Ice. News Bulletin of the Glaciological Society, No. 15, p. $14-15$.

Post, A. S. 1965. Alaskan glaciers: recent observations in respect to the earthquake advance theory. Science, Vol. I 48 , No. 3668 , p. $366-68$.

Tarr, R. S., and Martin, L. I914. Alaskan glacier studies. Washington, D.C., National Geographic Society, p. $168-97$. 